\title{
THERMALY ACTIVE INTERIOR PANELS WITH AN INTEGRATED ACTIVE AREA
}

\author{
Daniel KALÚS ${ }^{1 *}$, Mária KURČOVÁ ${ }^{1}$, Zuzana STRAKOVÁ ${ }^{1}$, Matej KUBICA ${ }^{1}$
}

\section{Abstract}

Panels with an integrated active area can be used for interior applications for walls, ceilings and floor heating, and alternatively as a wet or dry type of construction. At present, most panels with an integrated active area are made of gypsum boards with milled channels and embedded pipes. Some manufacturers already supply these panels with thermal insulation (Radwan et al., 2021; Zhang et al., 2020). Certain limitations, mainly regarding the diameter and material of the pipes, apply to the panels with channels milled in the gypsum board and embedded pipes. These limitations are closely related to the high cost of such panels and to the limited heat/cooling output. The disadvantages of these panels are eliminated by the construction of a thermal insulation panel with active thermal protection for application with an active heat transfer control system (indoor thermally active panel (ITAP)) in accordance with European Patent No. EP 2572057 B1 (Kalús, 2011).

\section{INTRODUCTION}

Patented panels with integrated active areas for interior applications mainly use thermo-insulation slabs with milled channels and embedded pipes (Figs. 1, 2) or system boards with embedded pipes. The panels can be furnished with a surface treatment in the form of, e.g., gypsum boards, which are used for dry construction. The panels can be made without a surface treatment as well; such panels can be used for wet construction. The application of capillary mats instead of pipes is also possible (Fig. 3). Panels with an active area for interior applications can be used as a heat carrier as well. Such panels are not constrained by the diameter of the pipes, and the thickness of the thermal insulation into which the pipes are integrated can be from $50 \mathrm{~mm}$, depending on the requirements for thermal protection of the building construction. In this case the heat/cooling output has greater variability, thanks to the possibility of greater flows of the heat/cool carrier (Boccardo et al., 2019).

\section{Address}

1 Dept. of Building Services, Slovak University of Technology in Bratislava, Faculty of Civil Engineering, Bratislava, Slovakia

* Corresponding author: zuzana.strakova@stuba.sk

\section{Key words}

- Indoor thermally active panels (ITAP),

- Active heating/cooling surface.

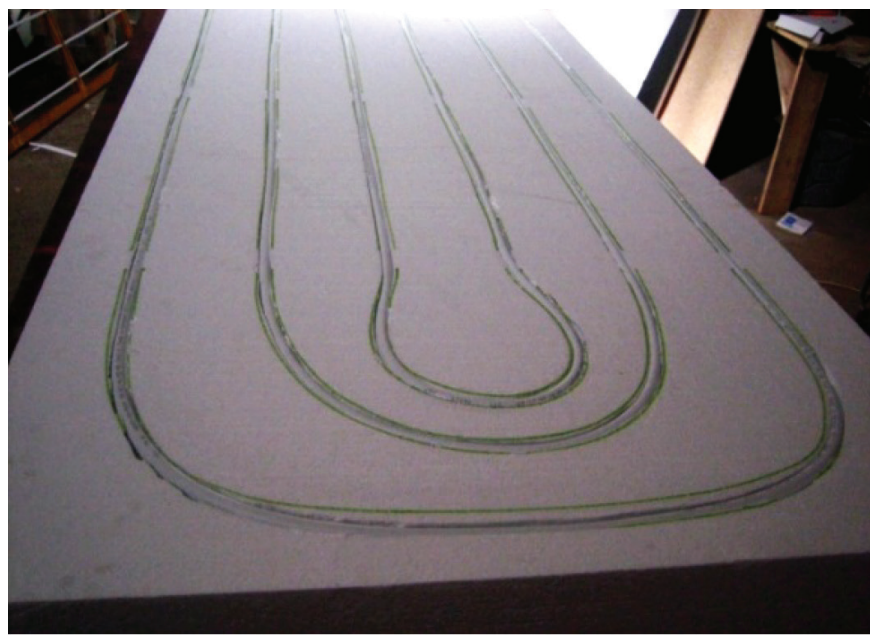

Fig. 1 Prototype of an ATIP panel - EPS, dimensions: $2000 x 1000 x$ $100 \mathrm{~mm}$; heat transfer medium: water (Kalús, 2011) 


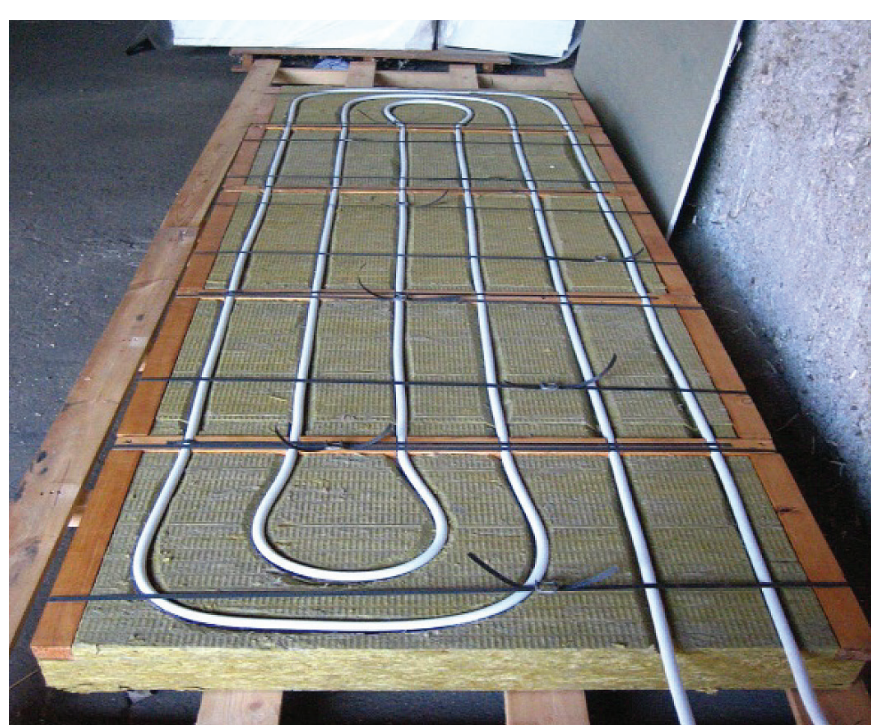

Fig. 2 Prototype of an ATIP panel - supporting frame - mineral wool, dimensions: $2000 \times 1000 \times 100 \mathrm{~mm}$; heat transfer medium: water (Kalús, 2011)

\section{CURRENT SITUATION WITH LARGE AREA APPLICATIONS RADIANT HEATING/COOLING}

In the case of large-area radiant heating/cooling, we recognize two basic solutions for the design of the heating surface:

- wet method - the heating surface is built-in, so it is an integral part of the building construction,

- dry method - the heating surface is separate; it is a heated plate, namely:

- fixed to one of the building structures,

- placed freely in the heated interior.

Thus, the heating/cooling system formed from the tube registers is concreted directly in the building structure, possibly under a plaster (Fig. 4), or, if the radiant heating is completed additionally, for

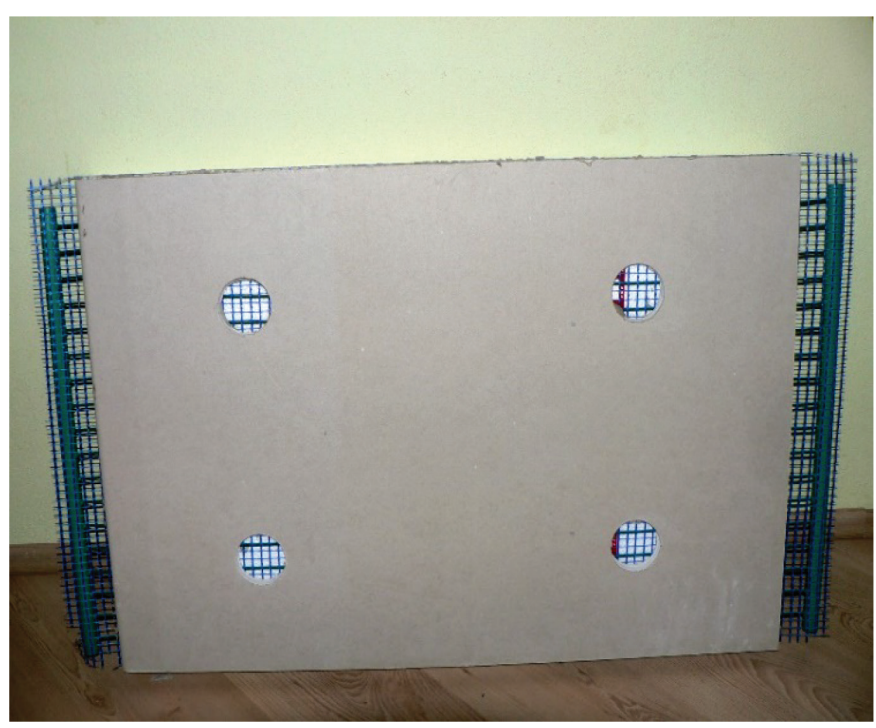

Fig. 3 Prototype of an interior panel with an integrated capillary mat; heat transfer medium: water (Kalús, 2011)

example, these registers can be hung under the load-bearing ceiling and covered with a plaster layer in the ceiling, i.e., the wet method, or panels with integrated tubular or capillary systems (e.g., in SD boards), i.e., the dry method, are used (Cvíčela, 2011; Janík, 2013; Janík and Kalús, 2012).

\subsection{Application of interior heating active panels for walls}

Thermally active interior wall panels can be applied to an auxiliary structure (Fig. 5) and also by directly gluing them to the masonry (Fig. 6), as shown in principle in the company documents of plasterboard manufacturers, respectively, radiant large-area heating/cooling panels with integrated tubes in SDK boards (Figs. 7, 8).
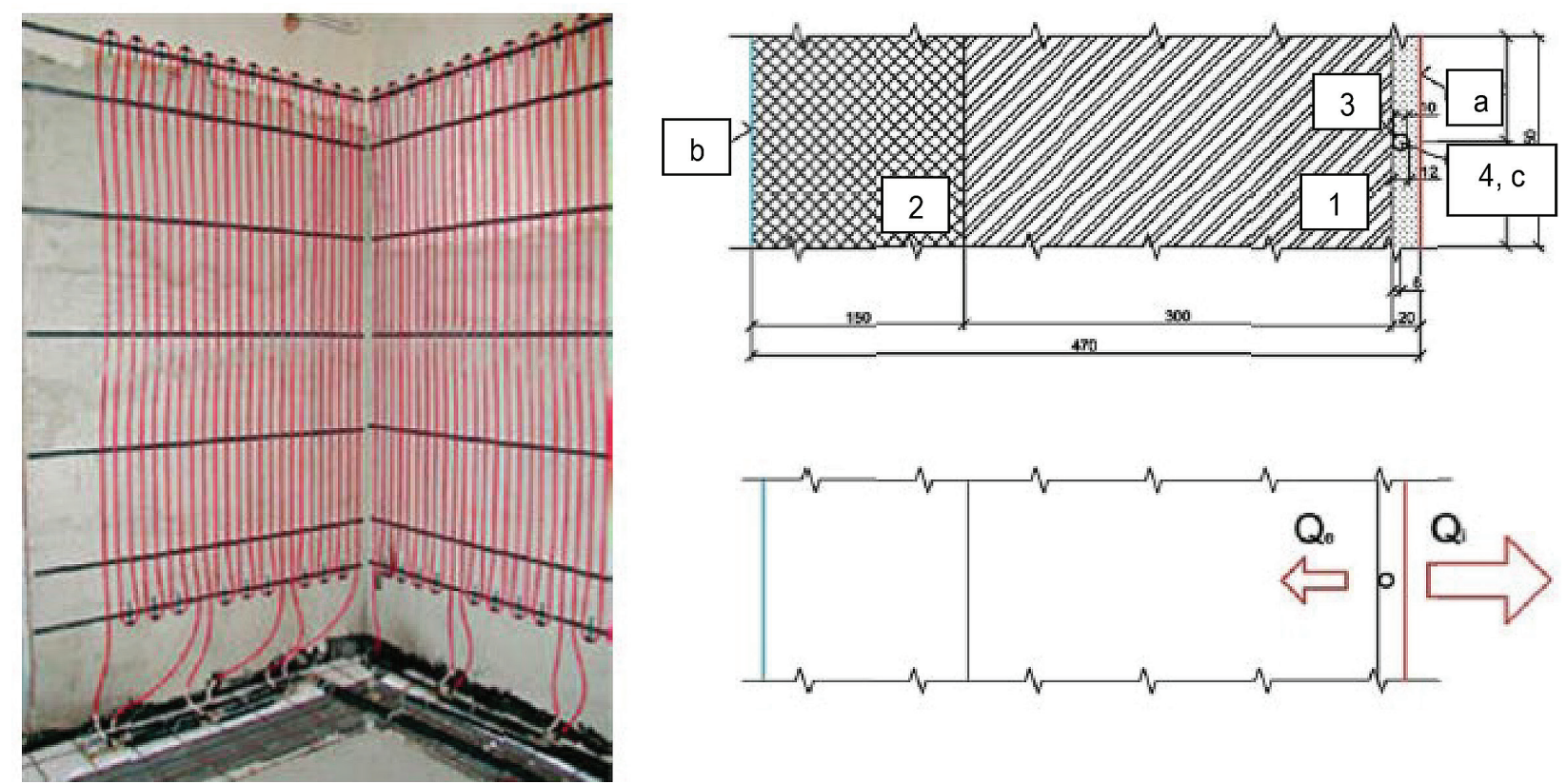

Fig. 4 Concealed wall energy system (Cvićela, 2011; https://slovensko.wolf.eu)

1 -wall, 2 -thermal insulation, 3 - interior plaster, 4 - heating/cooling pipe, a - interior surface temperature, $b$ - outer surface temperature, $c$-heat transfer medium temperature, $Q_{e}$ - heat flow from the pipe towards the exterior, $Q_{i}$ - heat flow from the pipe towards the interior 


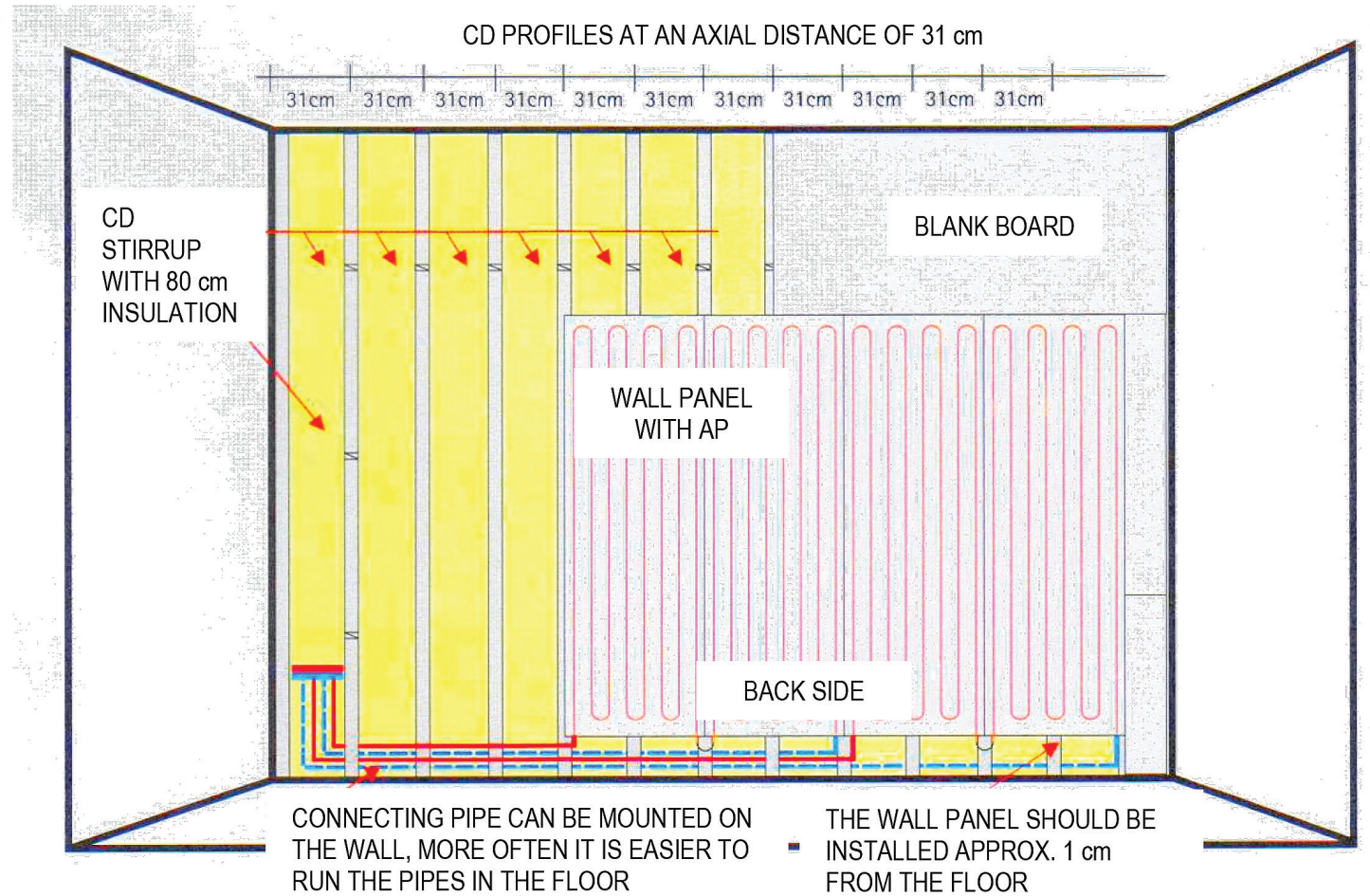

Fig. 5 Principle of the application of interior wall panels with an integrated oven to the auxiliary structure (https://slovensko.wolf.eu)

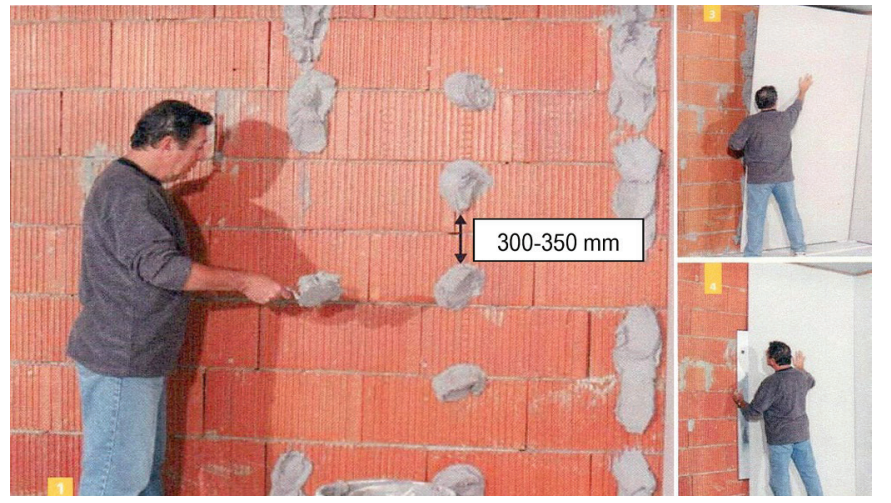

Fig. 6 Principle of the application of interior wall panels with an integrated glue oven (https://www.knauf.sk; https://www.rigips.sk)

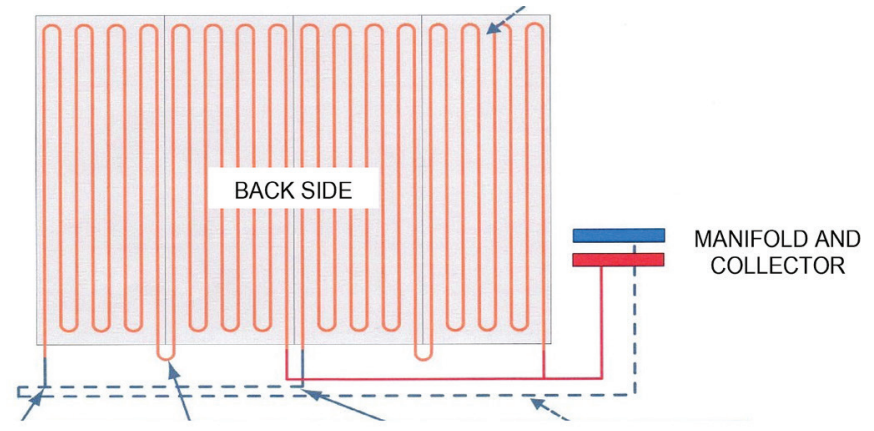

INTERCONNECTION OF INDIVIDUAL HEATING SEGMENTS BY MEANS OF PRESS CONNECTORS

Fig. 8 Principle of the connection of thermally active interior wall panels with an integrated oven by means of a Tichelmann connection (https://slovensko.wolf.eu)

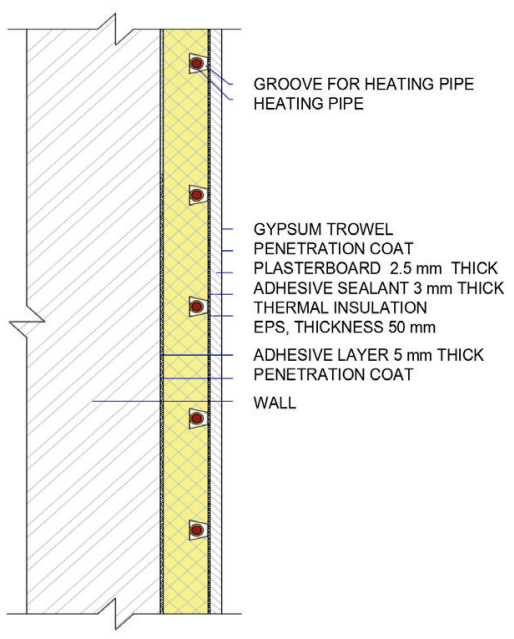

Fig. 7 Principle of the installation of thermally active interior wall panels with an integrated oven in thermal insulation boards covered with a top plate, e.g., pasteboard (Kalús, 2011) 


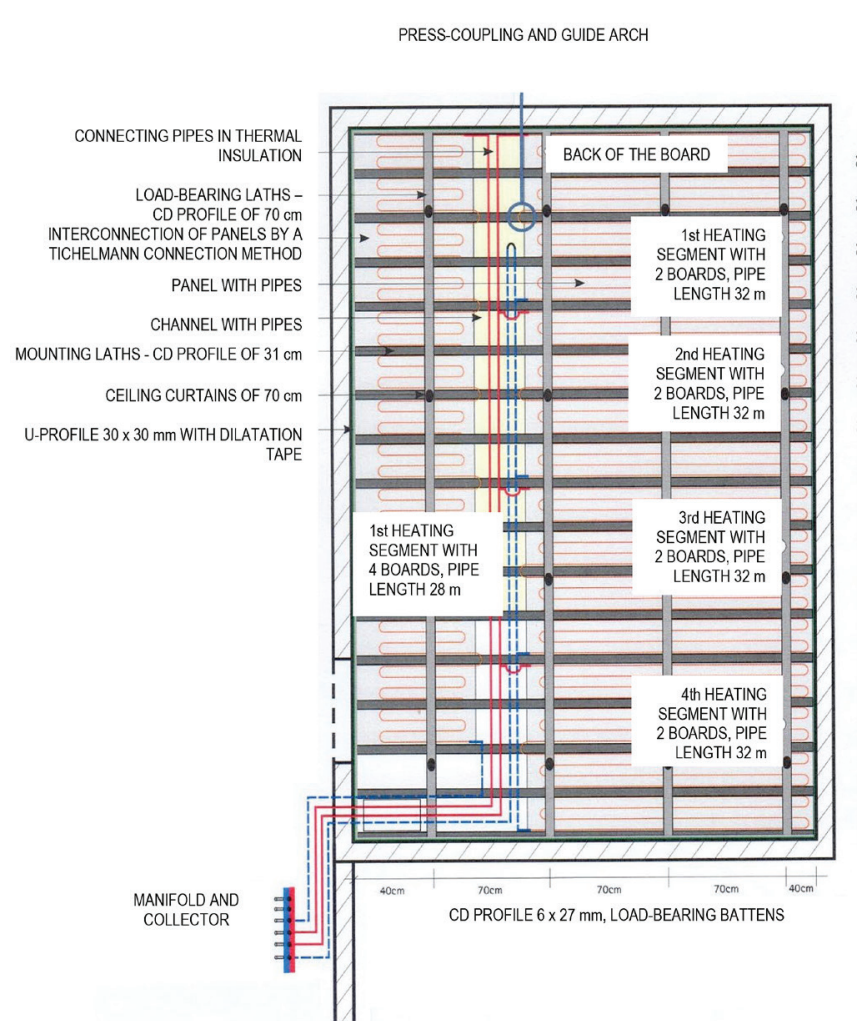

Fig. 9 Principle of the connection of thermally active interior ceiling panels with an integrated oven (https://slovensko.wolf.eu)

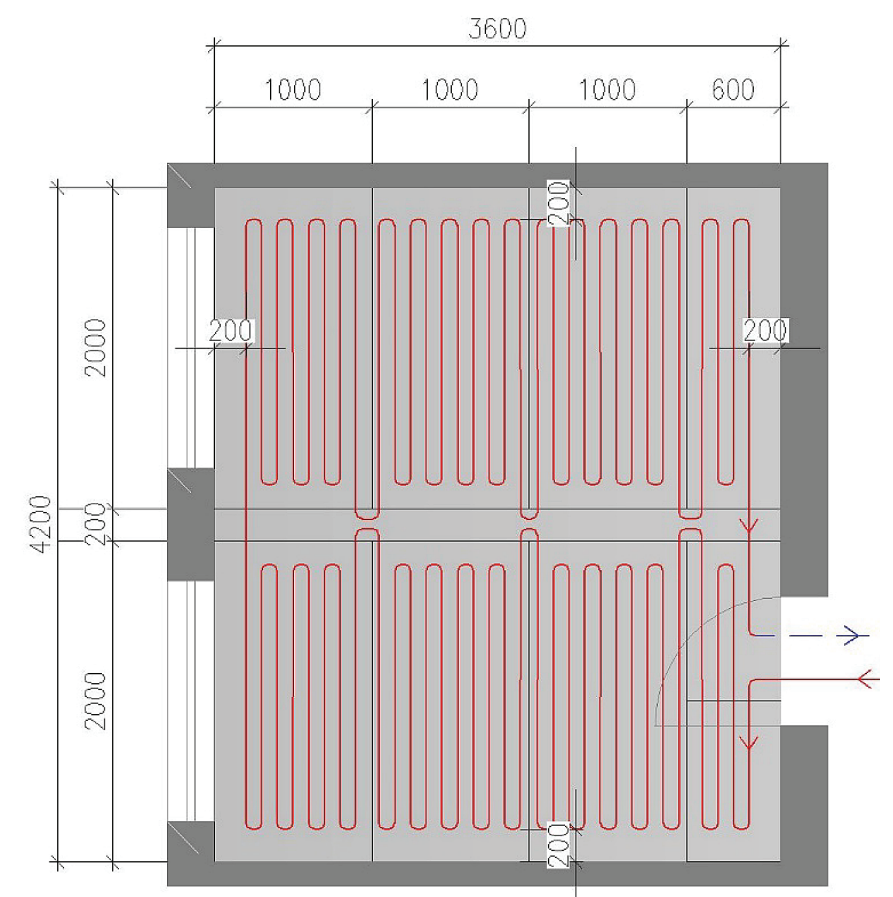

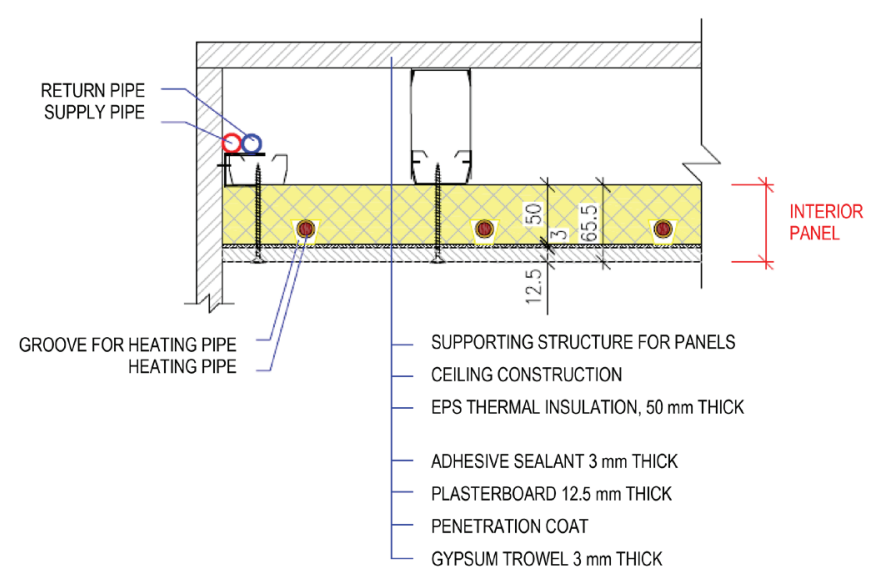

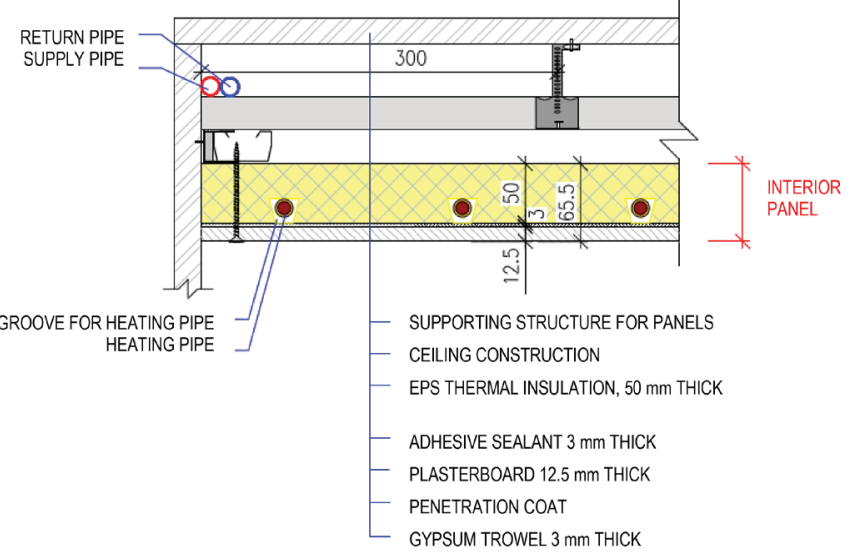

Fig. 10 Details of the anchoring of the ceiling panels with integrated pipes (Kalús, 2011)

\section{WET CONSTRUCTION METHOD}

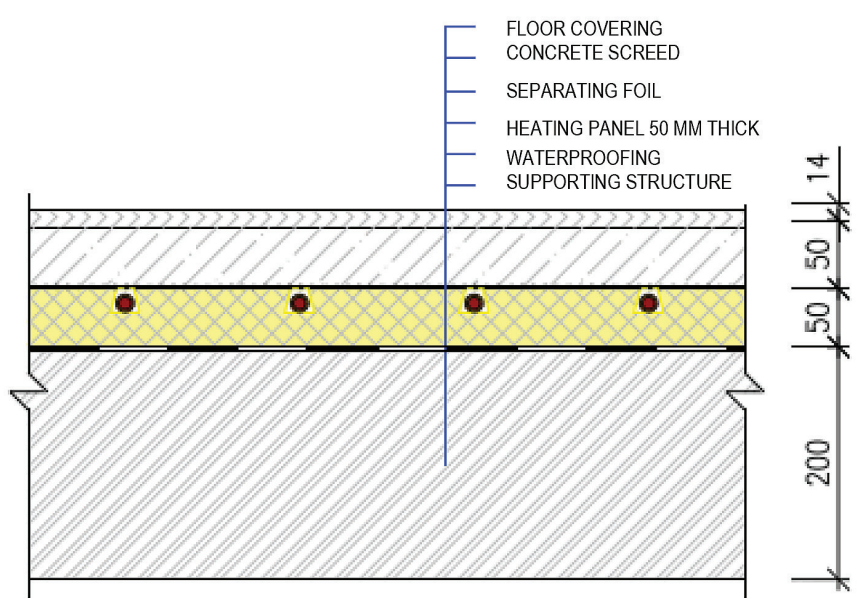

Fig. 12 Details of the wet construction of floor heating by interior panels with integrated pipes - accumulation heating (Kalús, 2011; Cvíčela and Kalús, 2009)

Fig. 11 Floor plan of interior floor panels with integrated pipes (Kalús, 2011; Cvíčela and Kalús, 2008) 


\subsection{Application of thermally active interior ceiling panels}

Figure 9 shows the application of thermally active interior ceiling panels with an integrated oven to an auxiliary structure. This procedure, respectively, radiant large-area heating / cooling panels with integrated pipes in plasterboard, is generally known from gypsum board manufacturers.

Details of the anchoring of the interior ceiling panels are shown in Fig. 10.

\subsection{Application of thermally active interior floor panels}

Interior panels with integrated pipes can also be applied to floor heating, by either wet or dry constructions. Fig. 11 shows a floor plan for heating the floor of a room. Fig. 12 shows the details of the wet construction of the floor heating by interior panels with integrated pipes, and Fig. 13 shows the details of a dry construction.

Thermally active interior panels with an integrated active area formed by channels with thermally treated air as the heat carrier can be used for large-area heating/cooling of floors, walls and ceilings. Fig. 14 shows a floor plan for heating the floor of one room. Fig. 15 shows the details of the dry and wet construction of floor heating by interior panels with integrated air channels.

\section{CONCLUSIONS}

Thermally active interior panels (ITAP) with an integrated active surface combine existing building and energy systems in an innovative way into one compact unit and thus create combined building and energy systems. These are building structures with an internal energy source. Low heat losses, respectively thermal gains, predict the application of low-temperature heating, respectively high temperature cooling systems such as heating/cooling large floor areas, walls and ceilings. The main benefit of ITAP panels is the possibility of unified and prefabricated production. At the same time, they represent a reduction of production costs due to their technological production process, a reduction in assembly costs due to the reduction of steps, their implementation on the construction site, and a reduction in the implementation time due to their method of application.

\section{DRY CONSTRUCTION METHOD}

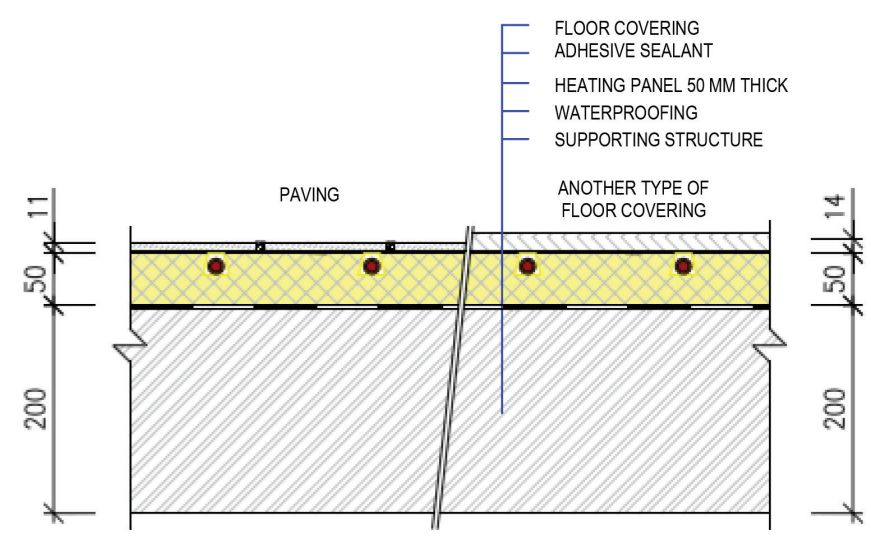

Fig. 13 Details of the dry construction of floor heating by interior panels with integrated pipes - direct heating (Kalús, 2011; Cvičela and Kalús, 2009)

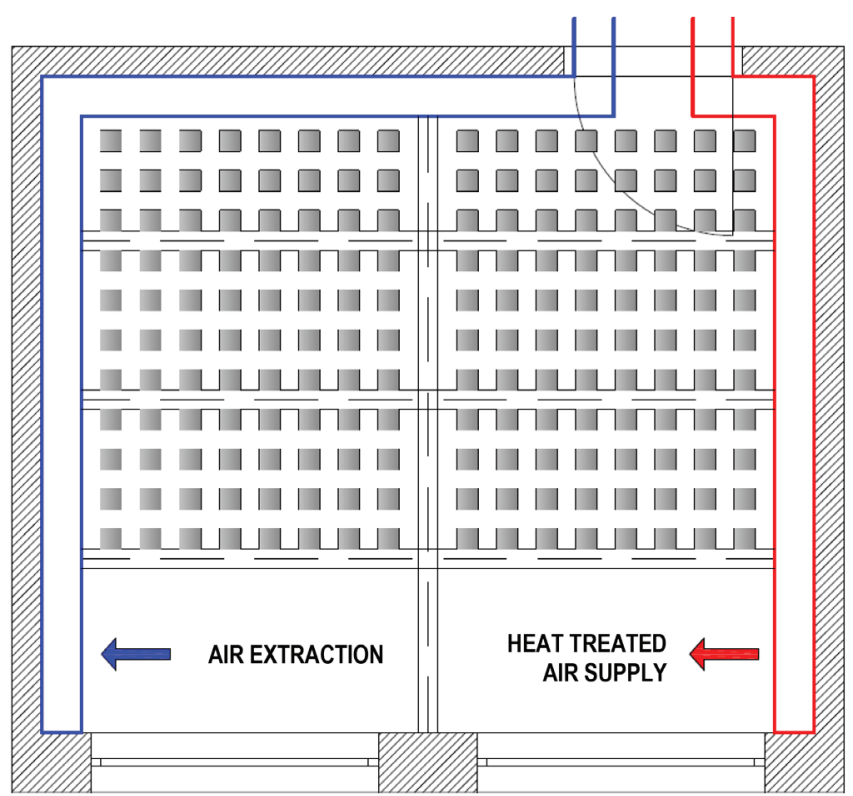

Fig. 14 Floor plan of interior floor panels with an integrated air channel (Kalús, 2011; Cvićela and Kalús, 2010)

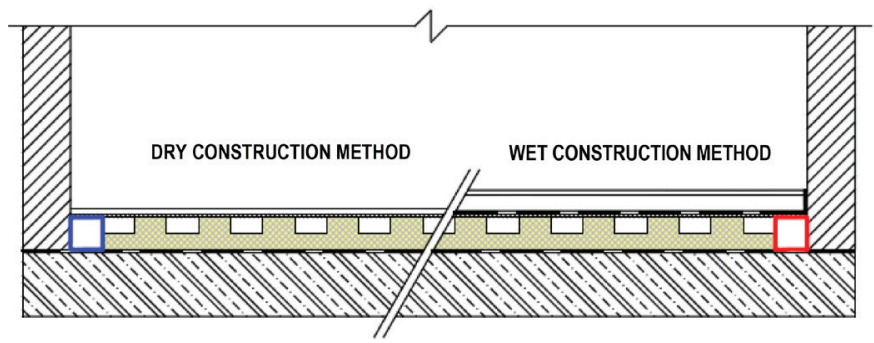

Fig. 15 Details of the dry and wet construction of floor heating by interior panels with integrated air channels (the panel consists of an insulation board with channels, which is covered by and glued to a large-area board, made, e.g., of gypsum) (Kalús, 2011; Kalús and Cvičela, 2013; Janík and Kalús, 2013) 


\section{REFERENCES}

Boccardo, L. B. - Kazanci, O. B. - Allerhand, J. Q. - Olesen, B. W. (2019) Economic comparison of TABS, PCM ceiling panels and all-air systems for cooling offices. In: Energy and Buildings, ISSN 0378-7788. Vol. 205. Availableat: https://doi.org/10.1016/j. enbuild.2019.109527, (accessed at 15/12/2019).

Cvíčela, M. (2011) Analýza stenových energetických systémov. Dizertačná práca (Analysis of wall energy systems. Dissertation work). Bratislava: Slovak University of Technology in Bratislava, Faculty of Civil Engineering, SVF-13422-17675, 119 p. [in Slovak].

Cvíčela, M. - Kalús, D. (2008) Energetické systémy s aktívnou tepelnou ochranou (Energy systems with active thermal protection). In: Indoor climate of buildings 2008: Environmental assessment and energy certification of buildings. Proceedings of the $19^{\text {th }}$ conference. Tatranská Lesná, 2.-3.12.2008. Bratislava: Slovak Society for Environmental Engineering, ISBN 978-80-89216-26-0, $87-90$ pp. [in Slovak].

Cvíčela, M. - Kalús, D. (2009) Analýza stenových energetických systémov (Analysis of wall energy systems). In: Indoor climate of buildings 2009: Environmental assessment of the indoor environment of buildings. Proceedings of the $20^{\text {th }}$ conference. Tatranská Štrba, 1.-2.12.2009. Bratislava: Slovak Society for Environmental Engineering, ISBN 978-80-89216-31-4, 179-182 pp. [in Slovak].

Cvíčela, M. - Kalús, D. (2010) Nové trendy v oblasti stenových energetických systémov (New trends in the field of wall energy systems). In: Vykurovanie (Heating) 2010: Energy efficiency of heat production, distribution and transfer systems. Proceedings of the $18^{\text {th }}$ conference. Lubovňa, 1.-5.3.2010. Bratislava: Slovak Society for Environmental Engineering, ISBN 978-80- 89216-32-1, 551554 pp. [in Slovak].

Cvíčela, M. - Kalús, D. (2010) Stenové energetické systémy vhodné na aplikáciu $v$ nizkoenergetických a energeticky pasivnych domoch (Wall energy systems suitable for application in low-energy and energy-passive houses). In: TZB Haustechnik, ISSN 1210356X, Vol. 18, No. 3, 24-25 pp. [in Slovak].

Janík, P. (2013) Optimalizácia energetických systémov s dlhodobou akumuláciou tepla. Dizertačná práca (Optimization of energy systems with long-term heat accumulation. Dissertation work). Bratislava: Slovak University of Technology in Bratislava, Faculty of Civil Engineering, SvF-13422-16657, 185 p. [in Slovak].
Janík, P. - Kalús, D. (2012) Výsledky experimentálnych meraní v rodinnom dome s kombinovaným stavebno-energetickým systémom s aktívnou tepelnou ochranou (Results of experimental measurements in a family house with combined building and energy system with active thermal protection). In: Indoor climate of buildings 2012: Environmental versus energy aspects of building design. Proceedings of the $23^{\text {rd }}$ conference. Štrbské Pleso, 29.30.11.2012. Bratislava: Slovak Society for Environmental Engineering, ISBN 978-80-89216-52-9, 85-88 pp. [in Slovak].

Janík,P.-Kalús, D.(2013) Vyhodnotenieprevádzkyenergetickejstrechy $v$ experimentálnom rodinnom dome (Evaluation of energy roof operation in an experimental family house). In: Nízkoteplotné vykurovanie (Low temperature heating) 2013. Proceedings of the $13^{\text {rd }}$ conference. Donovaly, 22.-23.5.2013. Bratislava: Slovak Society for Environmental Engineering, ISBN 978-80-89216-54-3, 28-32 pp. [in Slovak].

Kalús, D. (2011) European Patent No. EP 2572057 B1: Heat insulating panel with active regulation of heat transition. Date of publication and mention of the grant of the patent: 15.10.2014 In: Bulletin 2014/42 European Patent Office, international application No.: PCT/SK2011/000004, international publication No.: WO 2011/146025 (24.11.2011 Gazette 2011/47), 67 p.

Kalús, D. - Cvíčela, M. (2013) Stenové energetické systémy vhodné pre aplikáciu $v$ pasivnych domoch (Wall energy systems suitable for application in passive houses). In: Stavebnictví (Czech Republic), ISSN 1802-2030, Vol. 4, No. 1, 52-54 pp. [in Slovak].

Radwan, A. - Katsura, T. - Ding, L. - Serageldin, A.A. - El-Seesy, A.I. - Nagano, K. (2021) Thermal performance analysis of a new multi-segmented mini channel-based radiant ceiling cooling panel. In: Journal of Building Engineering, ISSN 2352-7102. Available at: https://doi.org/10.1016/j.jobe.2021.102330, (accessed at 25/02/2021).

Zhang, Ch. - Pomianowski, M. - Heiselberg, P. K. - Yu, T. (2020) A review of integrated radiant heating/cooling with ventilation systems- Thermal comfort and indoor air quality, Energy and Buildings. In: Journal of Building Engineering, ISSN 0378-7788. Vol. 223. Available at: https://doi.org/10.1016/j.enbuild.2020.110094, (accessed at 15/09/2020). 